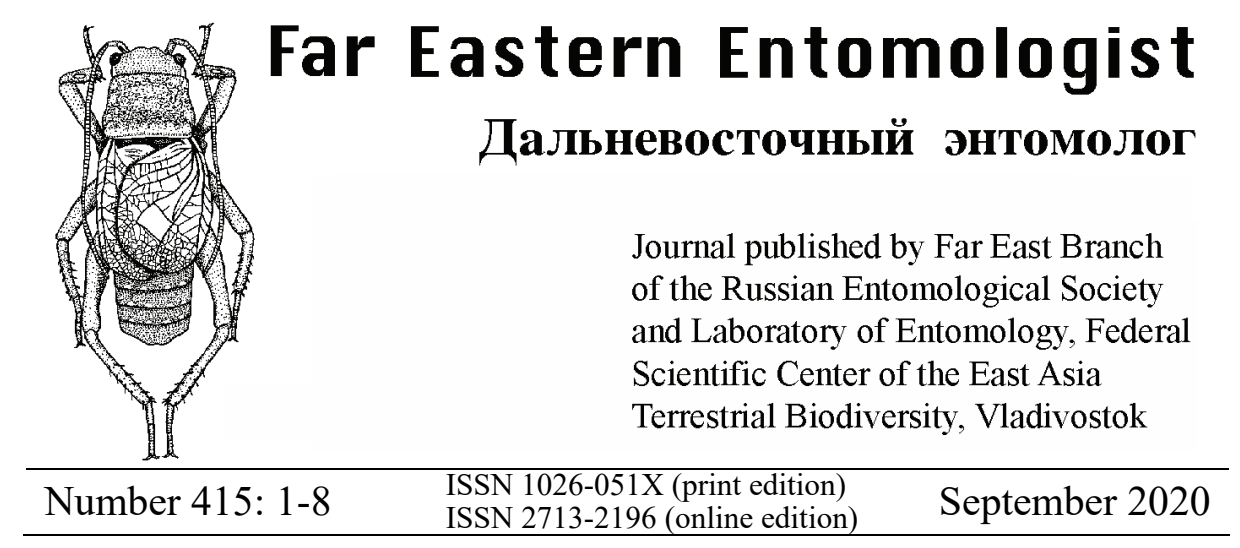

https://doi.org/10.25221/fee.415.1

http://zoobank.org/References/F902F34D-764A-4460-AA47-9751FD831483

\title{
DESCRIPTION OF A NEW SPECIES OF THE GENUS \\ COCKERELLIELLA SUNDARARAJ ET DAVID, 1992 \\ (HEMIPTERA: ALEYRODIDAE) FROM THE LITTLE ANDAMAN ISLAND, INDIA
}

\author{
A. K. Dubey \\ Zoological Survey of India, Andaman and Nicobar Islands, Port Blair, 744102, \\ India.E-mail: anil.2kd@gmail.com
}

Summary. A new whitefly, Cockerelliella setosus Dubey, sp. n., is described from the Little Andaman Island in Bay of Bengal. It was found infesting Aporosa octandra (Buch.-Ham. ex D. Don) Vickery (Pyllanthaceae). Puparia of the new species differ from all the described Cockerelliella species in having much longer cephalic and caudal setae compared to the eighth abdominal setae, combined with narrow submarginal ventral fold and submedian row of tubercles. Line drawings and microphotographs of holotype of the new species are given. An updated key to the puparia of Indian species of Cockerelliella is also provided.

Key words: whitefly, Aleyrodidae, taxonomy, new species, Andaman Islands, Bay of Bengal.

А. К. Дубей. Описание нового вида рода Cockerelliella Sundararaj et David, 1992 (Hemiptera: Aleyrodidae) с острова Малый Андаман, Индия // Дальневосточный энтомолог. 2020. N 415. С. 1-8.

Резюме. С острова Малый Андаман в Бенгальском заливе описан новый вид белокрылок Cockerelliella setosus Dubey, sp. n. Этот вид обнаружен на листьях 
Aporosa octandra (Buch.-Ham. ex D. Don) Vickery из семейства филлантовых (Pyllanthaceae) отряда мальпигиецветных. Пупарии нового вида отличаются от всех известных видов рода Cockerelliella наличием более длинных головных и хвостовых щетинок (по сравнению с щетинками IX сегмента брюшка), а также узкой каудальной бороздкой и рядом субмедиальных бугорков. Приводятся рисунки и фотографии голотипа нового вида, а также определительная таблица пупариев индийских видов рода Cockerelliella.

\section{INTRODUCTION}

The whitefly genus Cockerelliella (type species C. indica Sundararaj et David, 1992) was described from India (Sundararaj \& David, 1992). So far, the genus is represented by 20 species worldwide including the new species described here. Many of them are described from the Indo-Malayan region (including Taiwan and Thailand) with a single species, C. citri (Corbett, 1935) reported from Australia. Cockerelliella species differ little in their pupal morphology and in need of revision. Further, while describing the genus Cockerelliella, authors noted "longitudinal moulting suture reaching margin" (Sundararaj \& David, 1992), this error continued misleading researchers in Indian literature till recent publication of Pushpa \& Sundararaj (2009). The author has not seen the longitudinal moulting reaching margin in any of the Cockerelliella species so far examined, and clarifies here that the longitudinal moulting suture reaching cephalothoracic suture only, and agrees with the diagnosis for genus given by Martin (1999).

The genus Cockerelliella is recorded here for the first time from the Andaman Islands. The Little Andaman Island is located on geographical coordinates from $10^{\circ} 30^{\prime}$ to $10^{\circ} 54^{\prime} \mathrm{N}$ and from $92^{\circ} 20^{\prime}$ to $92^{\circ} 54^{\prime}$ E covering an area of $737 \mathrm{sq} \mathrm{km}$. A new species, $C$. setosus sp. n. is described and illustrated below.

Also, an updated key to puparia of Cockerelliella species so far known from India is given, based on the available literature. In life, Cockerelliella species are observed with median pigmentation (erroneously referred to as 'brown patch') which disappears in slide mounts, and the crescent-shaped plates along posterior margin of the cephalothoracic suture is common and almost always present, as well as sexual dimorphism is entirely overlooked in all the species. Possibly, this is due to availability of puparia in small numbers, and as and when studies on large population of species differing in puparial size or in number of a few marginal crenulations only may prove to be synonymous.

\section{MATERIAL AND METHODS}

The new whitefly pupal cases were collected on the Little Andaman Island along with the host plant leaves in cloth coated A4 size paper envelops and carried to Andaman and Nicobar Regional Centre (ANRC), Zoological Survey of India (ZSI), Port Blair for further studies. Puparia were mounted following Dubey \& David (2012). Photograph of the puparial habitus on leaf were taken by using a Leica 
made M205 A microscope attached to an auto-montage camera with a DFC500 configuration. A Labomed LX 400 compound microscope was used for identification; both microscopes belonged to the ANRC, ZSI in Port Blair, India. A Nikon made compound microscope Eclipse 50i attached to an auto-montage camera with DFC configuration was used for imaging holotype puparium. The microscope belonged to Andaman and Nicobar Regional Centre, Botanical Survey of India, Port Blair. The terminology for puparial morphology follows those of Bink-Moenen (1983), Martin (1985) and Gill (1990). Measurements were taken for all the type specimens.

The holotype and five paratypes are deposited in the National Zoological Collection, Zoological Survey of India, Kolkata (ZSI). One paratype is also deposited in the National Forest Insect Collection, Forest Research Institute, Dehradun (NFIC).

\section{TAXONOMY}

\section{Cockerelliella setosus Dubey, sp. $\mathbf{n}$.}

http://zoobank.org/NomenclaturalActs/8F84630E-598B-4CC2-9A28-B1929277631F

Figs 1-11

TYPE MATERIAL. Holotype - one female puparium on slide, India: Andaman and Nicobar Islands, Little Andaman Island, 10 $40^{\prime} 41.83^{\prime \prime} \mathrm{N}, 92^{\circ} 32^{\prime} 29.86^{\prime \prime} \mathrm{E}$, on Aporosa octandra, 2.II 2020, leg. A.K. Dubey (ZSI). Paratypes: six puparia on four slides, data same as the holotype (ZSI, NFIC).

DESCRIPTION. Puparium. White; shiny; dorsally flat; without secretion of wax; broadly rounded anteriorly, posteriorly narrow (Figs 1, 3); dimorphic, female 870-880 microns long, 700-770 microns wide; male 700-780 microns long, 540 680 microns wide. Found singly on the underside of leaves, only one puparium per leaf.

Margin. Smooth. Thoracic and caudal tracheal pores indicated in the margin as $\mathrm{C}$-shaped invaginations. Thoracic tracheal furrows absent. Caudal tracheal furrow present, inner margins of furrow with 10-11 crenulations, furrow filed with microtubercles (Figs 1, 10).

Dorsum. Cephalothorax separated from the dorsal disc by a suture, suture not extending to abdominal region. Median length of cephalothorax and abdomen 375 475 and 360-460 microns long, respectively. Median length of abdominal segment I-VII: 47-50, 40-45, 37-40, 35-37, 33-37, 32-37, 30-33, 40-43 microns long, respectively. Seven pairs of submarginal setae, one pair located each lateral to prothorax, above thoracic tracheal pores, meso-metathoracic suture or on metathorax, first abdominal segment, segment suture V/VI or segment VI, pockets or below, and two pairs on caudal region. Caudal furrow 118 microns long in female, 100 103 microns long in male. Geminate pores present in four rows, one row each along the submargin and submedian area and two rows in middle of these on subdorsal area. Two pairs of geminate pores present on the first abdominal segment, between metathoracic legs. 
Vasiform orifice. Subcordate (Figs 2, 10), 22-28 microns long, 35-38 microns long, inner margin smooth; operculum subcordate, entirely covering the orifice and obscuring the lingula, 20-25 microns long, 35-38 microns wide.

Venter. Narrow submarginal area demarcated by a fold. Paired ventral eighth abdominal setae 10-13 microns long, apart 30-45 microns. Antennae extending through inside prothoracic legs and reaching near base, 14 (5 microns keel) microns long. Adhesive sacs and spiracles visible.

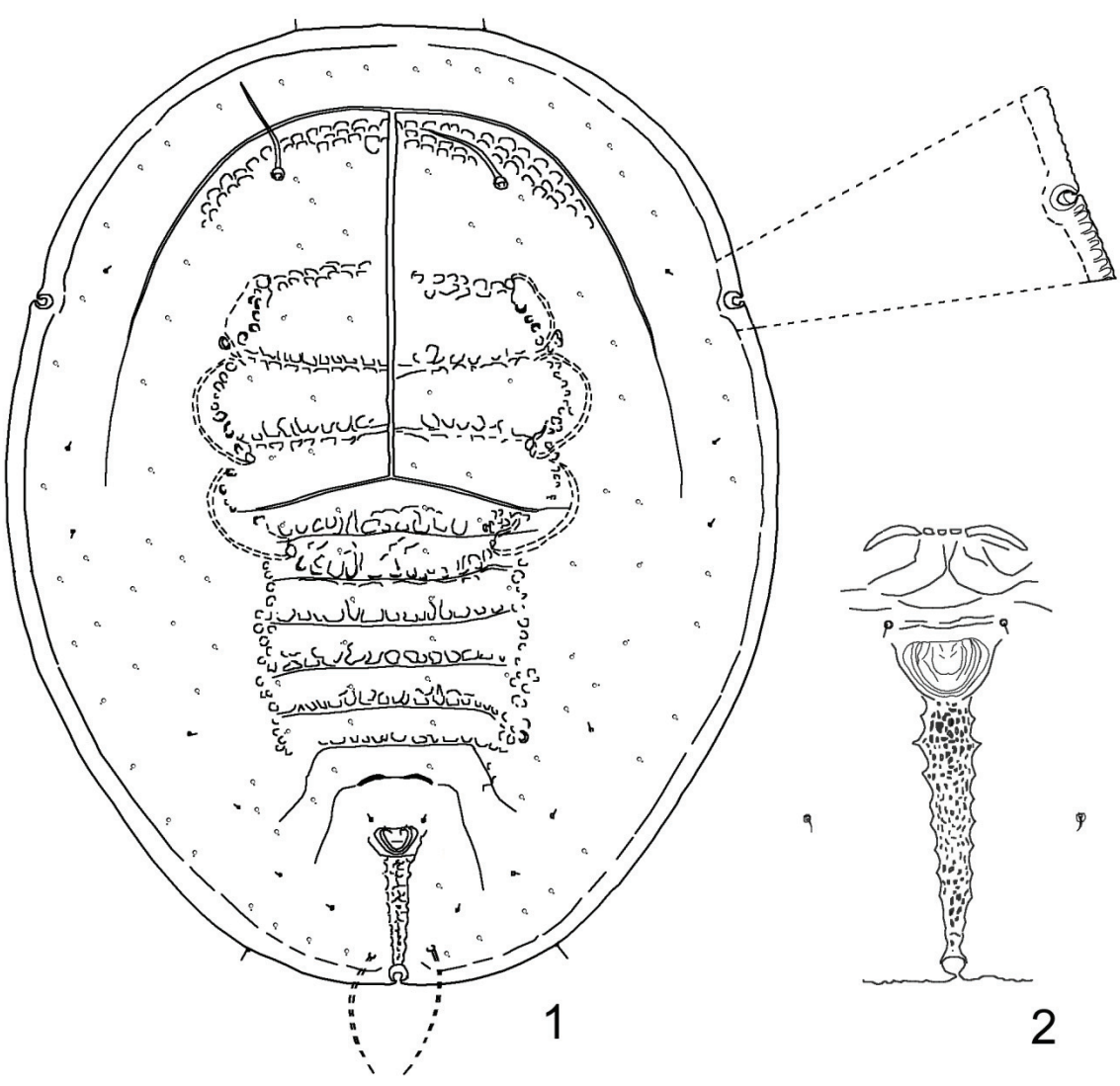

Figs 1, 2. Cockerelliella setosus sp. n.: 1 - holotype puparium; 2 - vasiform orifice and submarginal caudal end.

Chaetotaxy. Cephalic and caudal setae exceptionally longer than the eighth abdominal setae, 96 and 82-92 microns long, respectively. Eighth abdominal setae cephalolateral to vasiform orifice, 7-10 microns long, 43-48 microns apart. First abdominal setae absent. Anterior and posterior marginal setae prominent, 20-23 and 17-25 microns long, respectively. Submarginal setae 11-13 microns long. 

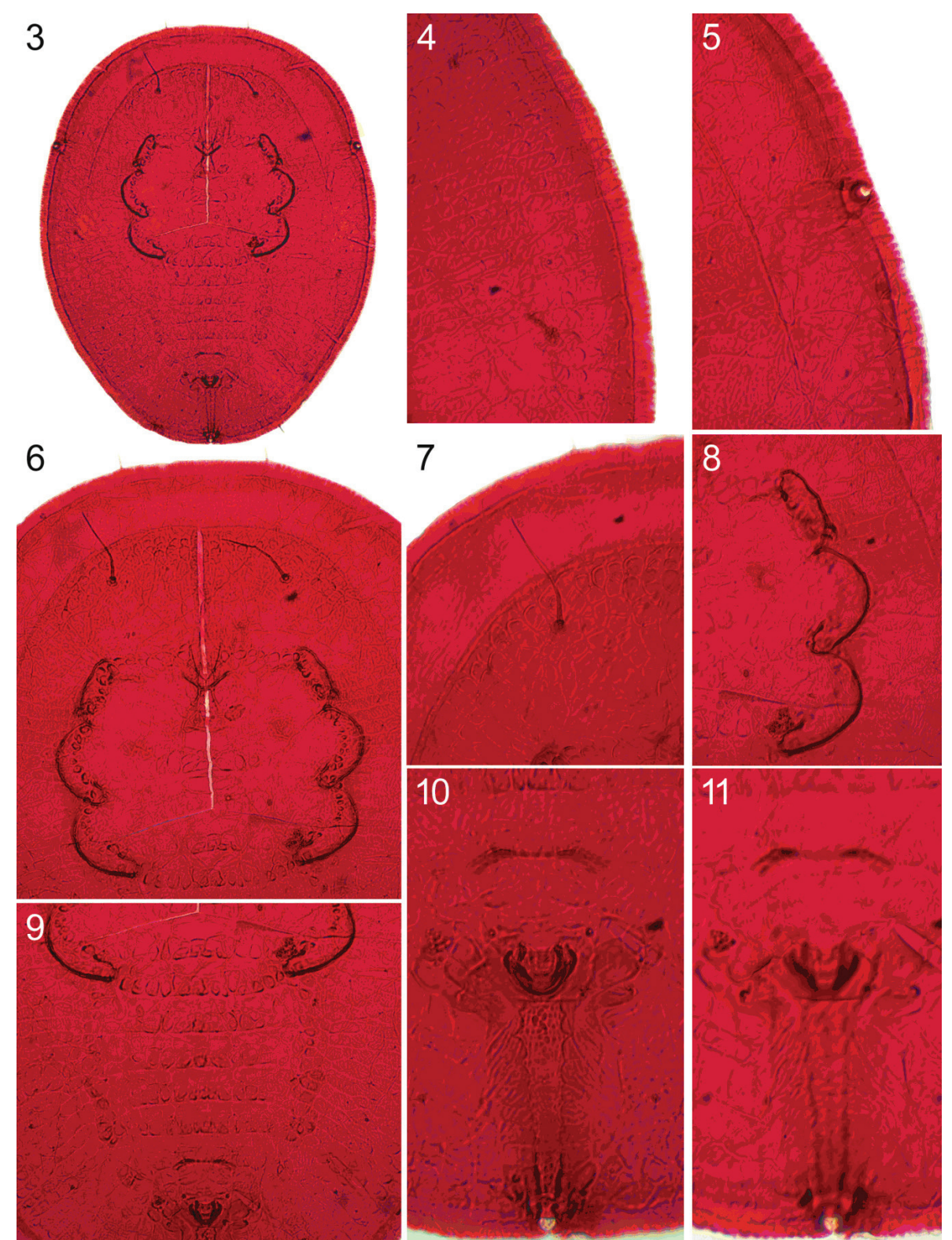

Figs 3-11. Cockerelliella setosus sp. n., holotype: 3 - puparium; 4 - margin; 5 - thoracic tracheal pore; 6 - cephalothorax; 7 - cephalic seta; 8 - submedian tubercles; 9 -abdominal segments; 10 - vasiform orifice, caudal furrow, caudal pore; 11 - ventral setae, caudal fold. 
HOST PLANT. Pyllanthaceae: Aporosa octandra (Buch.-Ham. ex D. Don) Vickery.

DISTRIBUTION. India: Andaman and Nicobar Islands, Little Andaman Island.

ETYMOLOGY. The species epithet 'setosus' is attributing exceptionally long dorsal setae.

DIAGNOSIS. Puparia of the Cockerelliella setosus sp. n. differ from all the Indian congeners in having much longer cephalic and caudal setae compared to the eighth abdominal setae, combined with narrow submarginal ventral fold and submedian row of tubercles. It differs from $C$. dioscoreae from India (Sundararaj \& David, 1992), C. schimae Lalneihpuia et Sundararaj, 2011 and C. williamsoni Lalneihpuia, 2011 in Chhakchhuak et al. (2011) from India in longer dorsal setae, structure of caudal furrow, also from later two in shape and dorsal sculpture. The new species differs from C. psidii (Corbett, 1935) described from Malaysia (Corbett, 1935) in shape, longer cephalic setae reaching beyond cephalothoracic furrow, ventral fold and in lacking a ring of papilla-like markings on the submargin; and from C. kamardini (Corbett, 1935) known from Malaysia (Corbett, 1935) in shape, larger size, shape of caudal furrow and in lacking submarginal ventral fold. Among these $C$. psidii has median patch on metathorax and abdominal segment I. I also believe that the longer cephalic and caudal setae are not host-correlated variations as only these two setae were longer and the host plant has smooth surfaces of leaves.

\section{Key to the puparia of Indian species of Cockerelliella}

1 Cephalic and caudal setae much longer than the eighth abdominal setae; cephalic setae reaching beyond cephalothoracic suture

C. setosus sp. $\mathbf{n}$.

- Cephalic and caudal setae minute, almost equal to the length of eighth abdominal setae; cephalic setae not reaching beyond cephalothoracic suture 2

2 Ventral submargin differentiated from subventral area by a fold ..................................... 3

Ventral submargin not differentiated from subventral area by a fold .............................. 5

3 Dorsal and submarginal setae pointed; seven pairs of submarginal setae, 2 pairs on cephalothorax and five pairs on abdomen

- Dorsal setae fimbriate, most of the submarginal setae fimbriate; ten pairs of submarginal setae, 5 pairs each on cephalothorax and abdomen, one abdominal pair pointed

C. rotunda Regu et David, 1993

4 Subdorsum and submargin with papilla-like structures; a distinct row of crescent-shaped papilla-like structures extending from lateral of vasiform orifice to anterior end of cephalothorax absent

C. somnathensis Sundararaj, 2000

- Subdorsum and submargin without papilla-like structures; a distinct row of crescentshaped papilla-like structures extending from lateral of vasiform orifice to anterior end of cephalothorax present C. dioscoreae Sundararaj et David, 1992

5 Caudal furrow smooth 6

- Caudal furrow with distinct polygonal markings or papillae like markings or tessellated

Median pigmentation present on metathoracic and abdominal segment I; submedian papillae present; cephalothoracic tubercles absent

C. quaintancei Sundararaj et David, 1992 
- Median pigmentation absent on metathoracic and abdominal segment I; submedian papillae absent; 5 pairs of tubercles present on cephalothorax

C. kudremukhensis Sundararaj, 2007

7 Subdorsum with three to seven pairs of enlarged tubercles ........................................ 8

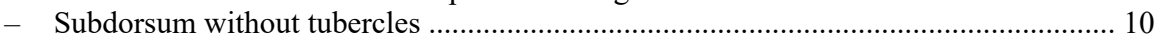

8. Dorsum without distinct granules; with a submedian row of papillae; subdorsum with papilla-like structures along the cephalothoracic suture at cephalic region ..................... 9

- Dorsum with distinct granules; without a submedian row of papillae; subdorsum without papilla-like structures along the cephalothoracic suture at cephalic region

C. dehradunensis (Jesudasan et David, 1991)

9 Vasiform orifice without lateral tubercles; median pigmentation absent on metathorax, abdominal segment I, VII and VIII; dorsum tessellated

C. meghalayensis Sundararaj et David, 1992

- Vasiform orifice with lateral tubercles; median pigmentation present on metathorax, abdominal segment I, VII and VIII; dorsum with polygonal papillae-like structures

C. cinnamomi Pushpa et Sundararaj, 2009

10 Margin crenulated; caudal furrow with polygonal markings ....................................... 11

- Margin smooth; caudal furrow tessellated ........ C. vijendrai Pushpa et Sundararaj, 2009

11 Puparium 0.75-0.93 mm long, a submedian row of papillae-like structures on dorsum present 12

- Puparium 0.94-1.19 mm long; a submedian row of papillae-like structures on dorsum absent ............................................................ C. zingiberae Sundararaj et David, 1992

12 Margin with 22-24 crenulations in $0.1 \mathrm{~mm}$; submargin without papillae-like structures, with striations; dorsum tessellated C. indica Sundararaj et David, 1992

- Margin with 13-15 crenulations in $0.1 \mathrm{~mm}$; submargin with papillae-like structures, without striations; dorsum with numerous papillae-like structures

C. splendens Meganathan et David, 1994

\section{ACKNOWLEDGEMENTS}

Thanks are due to the Director, ZSI, Kolkata, OC, ZSI/ANRC and T. A. M. Jagdeesh, BSI/ANRC, Port Blair for microscopic facilities. The Ministry of Environment, Forests and Climate Change, New Delhi, India is greatly acknowledged for financial assistance.

\section{REFERENCES}

Bink-Moenen, R.M. 1983. Revision of the African whiteflies (Aleyrodidae), mainly based on a collection from Tchad. Monografieën Nederlandse Entomologische Vereniging, 10: 1210.

Chhakchhuak, Lalneihpuia \& William, S.J. 2011. Taxonomic studies on the whitefly (Aleyrodidae: Hemiptera: Insecta) fauna of Mizoram. Memoirs of the Entomological Society of India, 16: 1-111.

Corbett, G.H. 1935. Malayan Aleurodidae. Journal of the Federated Malay States Museums, 17: 722-852.

Dubey, A.K. \& David, B.V. 2012. Collection, preservation and preparation of specimens for taxonomic study of whiteflies (Hemiptera: Aleyrodidae). P. 1-19. In: David, B.V. (Ed.). The whiteflies or mealywing bugs: biology, host specificity and management. Lambert Academic Publishing, Germany. 
Gill, R.J. 1990. The morphology of whiteflies. In: Gerling, D. (Ed.). Whiteflies: their bionomics, pest status and management. Andover: Intercept, pp.13-46.

Jesudasan, R.W.A. \& David, B.V. 1991. Taxonomic studies on Indian Aleyrodidae (Insecta: Homoptera). Oriental Insects, 25: 231-434.

Martin, J.H. 1985. The whitefly of New Guinea (Homoptera: Aleyrodidae). Bulletin of the British Museum (Natural History) (Entomology), 50: 303-351.

Martin, J.H. 1999. The whitefly fauna of Australia (Sternorrhyncha: Aleyrodidae), a taxonomic account and identification guide. Technical Paper, CSIRO Entomology. Canberra, 38: 1-197.

Pushpa, R. \& Sundararaj, R. 2009. Whiteflies of the genus Cockerelliella Sundararaj and David (Hemiptera: Aleyrodidae) of India with description of two new species. Biosystematica, 2: 29-36.

Regu, K. \& David, B.V. 1993. On three new species of whiteflies of the tribe Dialeurodini Sampson, 1943 (Aleyrodidae: Homoptera) from India. Journal of the Bombay Natural History Society, 89: 82-87.

Sundararaj, R. 2000. A new whitefly Cockerelliella somnathensis sp. n. from India (Insecta: Hemiptera: Aleyrodidae). Reichenbachia, 33: 313-316.

Sundararaj, R. 2007. On the genera Cockerelliella Sundararaj, gen. nov., with a key to the Indian genera of Aleyrodidae (Hemiptera). Oriental insects, 41(1): 243-257. DOI: https://doi.org/10.1080/00305316.2007.10417507

Sundararaj, R. \& David, B.V. 1992. On the genera Asialeyrodes Corbett and Cockerelliella gen. nov. from India. Journal of the Bombay Natural History Society, 88: 415-424. 